\title{
Evaluating mould colonisation and growth on MDF panels modified to sequester Volatile Organic Compounds
}

Stefanowski, Bronia; Ormondroyd, Graham; Curling, Simon

\section{International Wood Products Journal}

DOI:

$10.1080 / 20426445.2016 .1216052$

Published: 01/12/2016

Peer reviewed version

Cyswllt i'r cyhoeddiad / Link to publication

Dyfyniad o'r fersiwn a gyhoeddwyd / Citation for published version (APA):

Stefanowski, B., Ormondroyd, G., \& Curling, S. (2016). Evaluating mould colonisation and growth on MDF panels modified to sequester Volatile Organic Compounds. International Wood Products Journal, 7(4), 188-194. https://doi.org/10.1080/20426445.2016.1216052

Hawliau Cyffredinol / General rights

Copyright and moral rights for the publications made accessible in the public portal are retained by the authors and/or other copyright owners and it is a condition of accessing publications that users recognise and abide by the legal requirements associated with these rights. study or research.

- Users may download and print one copy of any publication from the public portal for the purpose of private

- You may not further distribute the material or use it for any profit-making activity or commercial gain

- You may freely distribute the URL identifying the publication in the public portal?

Take down policy

If you believe that this document breaches copyright please contact us providing details, and we will remove access to the work immediately and investigate your claim. 


\title{
Evaluating mould colonisation and growth on MDF panels modified to sequester Volatile Organic Compounds
}

\author{
B.K Stefanowski ${ }^{1}$, S.F Curling ${ }^{1}$, G.A Ormondroyd ${ }^{1,2}$ \\ ${ }^{1}$ The BioComposites Centre, Bangor University, Bangor, Gwynedd, United Kingdom LL57 \\ 2UW \\ ${ }^{2}$ Department of Architecture and Civil Engineering, University of Bath, Claverton Down, \\ Bath, BA2 7AY, UK
}

Corresponding Author: Stefanowski. B.K, Email: b.stefanowski@bangor.ac.uk

Key Words: MDF, Mould growth, colonisation, scavengers, VOCs

\begin{abstract}
The increased effort to improve energy efficiency, has led to improved "airtightness" of buildings, therefore leading to a reduction in ventilation. This results in an increase in concentration of indoor air pollutants, namely formaldehyde and volatile organic compounds (VOCs), which are suspected to contribute to "sick building syndrome" (SBS). There has been considerable research into the reduction of emissions via modification of current construction products. One modification is to use solid additives, "scavengers" in wood-based panels. This paper examines the effects of these scavengers on mould growth and the absorption of the VOCs; toluene, limonene and formaldehyde. The effects of the sorption of VOCs on the colonisation and growth of different mould species on modified MDF panels were also studied. It was shown that modified boards absorbed the 3 VOCs tested and this absorption did effect mould growth with differences observed in species present and in succession of mould colonisation.
\end{abstract}

\section{INTRODUCTION}

In recent years, indoor air quality and volatile organic compounds (VOCs) have received increasing attention. Coupled with this, there is an increased effort to improve the energy efficiency of buildings, which has resulted in the improved "air tightness" of buildings. An adverse effect of this, however, is the increase in the concentration of air pollutants, such as VOCs, inside homes where concentrations of many pollutants can be higher than in the outdoor environment (Rong et al., 2002). These VOCs often cause sick building syndrome (SBS) and have a number of symptoms; dizziness, eye and lung irritation, nausea and depression (Zhang and $\mathrm{Xu}, 2003$ ). Therefore, indoor air quality has become an issue of public health (Kim et al., 2011).

The World Health Organisation defines VOCs as compounds with a boiling point between $50^{\circ} \mathrm{C}$ to $260^{\circ} \mathrm{C}$ (WHO, 1989), which encompasses a great variety of compounds including, hydrocarbons, terpenes and aromatic hydrocarbons. Therefore it is an immense challenge to develop a product that will act as a sink to all VOCs.

Historically, there has been considerable research into the reduction of emissions from their original source, such as odourless paints and replacing formaldehyde based resins with biobased resins during wood-based panel production. More recently, there have been investigations into modifying wood-based construction materials and insulation materials to actively absorb formaldehyde and VOCs from the atmosphere. 
One such modification is to use chemical and solid additives, termed "scavengers", in woodbased panels, to bond with free VOCs and formaldehyde. These scavengers are added to panels during production, directly as part of the resin or as a solid additive. These scavengers usually take the form of commercially available chemicals. However, recent research has shown by-products from various industries have shown promise as low cost scavengers such as, waste materials (both inorganic (Kim, 2009) and organic (Pirayesh et al., 2013)). Waste peanut and pistachio nut shells have also shown potential use as a bio-absorbent of pollutants such as heavy metals and dyes in aqueous solutions (Johns et al., 1998; Tavakoli Foroushani et al., 2016; Witek-Krowiak et al., 2011; XU and LIU, 2008). Peanut shell has also shown potential to absorb $\mathrm{CO}_{2}$ (Deng et al., 2015). Walnut shell waste can be used as absorbent of copper ions (Kim et al., 2001).

The use of these additives, especially organic scavengers, raises the question as to what implication this sequestering of VOCs has on the resistance of modified MDF panels to microbial growth. Moulds will attack lignocellulosic materials, seeds, seedlings, food stuffs and books (Pasanen et al., 1992). Moulds can also attack synthetic floor coverings, airplane fuels, oils, glues, paints and textiles (Schmidt, 2006). Moulds rapidly colonise and grow on surface substrates and conidia develop rapidly. On timber, hyphae of mould fungi are able to penetrate the wood to a depth of a few millimetres and live on parenchyma cells that store sugar, starch and protein (Schmidt, 2006). Most moulds do not attack lignified cell walls, so therefore the wood strength properties remain unchanged (Viitanen, 1994).

However, the presence of moulds in damp buildings, can also contribute to SBS as many mould species' spores are known to cause health problems such as asthma and bronchitis (Fog Nielsen, 2003; Jarvis and Miller, 2004). The presence of moulds in construction materials can also increase a materials susceptibility to more destructive biological activity, such as decay fungi. Therefore it is highly important to study the implications of modifying current products to sequester VOCs on mould growth. It is widely known that the presence of formaldehyde will significantly prevent the growth of fungi on wood-based panels (Curling and Murphy, 1997; Dennis and Gaunt, 1974). However, little is known of the effects of absorbed VOCs on the colonisation and growth of moulds.

The work described below is an initial study developing a method to evaluate mould growth on modified MDF boards, modified with different organic scavengers from organic waste: peanut shell and walnut shell. The sorption of water and VOCs by the modified panels was also evaluated. The modified boards were "flooded" with VOCs, formaldehyde, toluene and limonene and then exposed to five different mould species: Trichoderma virens, Cladiosporum sphaerospermum, Chaetomium globosum, Aspergillus niger and Penicillium rubens.

\section{MATERIALS AND METHOD}

\section{Materials}

The three chemical solutions used in this experiment were chosen to represent different chemical groups of VOCs. Formaldehyde (F) represents polar VOCs (37\% concentration in water), limonene (L) represents nonpolar VOCs (99\% concentration) and toluene (T) represents aromatic VOCs (99\% concentration). These chemicals were sourced from Sigma Aldrich without further purification Sterile de-ionised water (W) was also used as a control. The materials tested were modified MDF construction materials and solid pine wood (Pinus sylvestris) as a control. The MDF panels were produced at pilot scale, using a mix of pine, fir and spruce wood chips and a urea-formaldehyde (UF) resin (12\%). 6 MDF panels were modified with different VOC scavengers, walnut shells and peanut shells, at three different 
loading percentages: 5, 10 and 15\% (on a dry weight basis). The peanut shell and walnut shell were milled to a particle size of $5 \mathrm{~mm}$. A Control MDF without scavengers was also produced. The boards were produced using a formaldehyde based resin, therefore all the samples were placed into conditioning room at $23^{\circ} \mathrm{C} \pm 1$ and $60 \pm 3 \%$, for 6 months to allow for de-gassing of free formaldehyde (Curling and Murphy, 1997).

Six replicates of each material were used for the sorption test of each VOC. As the analysis of mould growth was visual, dimensions of the test specimens were not critical but were approximately $50 \times 25 \mathrm{~mm}( \pm 2 \mathrm{~mm})$ at product thickness of $12 \mathrm{~mm}$. A further six replicates were used as sorption control specimens. All the test specimens were conditioned in standard conditions of $23^{\circ} \mathrm{C} \pm 1$ and $60 \pm 3 \% \mathrm{RH}$ until a constant mass was reached.

\title{
Moulds
}

All the mould species were purchased from Fungal Biodiversity Centre, Institute of the Royal Netherlands Academy of Arts and Science (KNAW). The mould species selected for use in testing are representative of species commonly found within buildings and used in standards (BS 1982-3):

\author{
1. Cladiosporum sphaerospermum (Penz) CBS 122.63 \\ 2. Chaetomium globosum (Kunze ex Fr.) CBS 107.14 \\ 3. Penicillium rubens (Biourge) CBS 401.92 \\ 4. Trichoderma virens (J.H. Mill, Giddens \& A.A. Foster) CBS 100946 \\ 5. Aspergillus niger (M. Frank) CBS 101698
}

\section{Preparation of spores}

Using well sporulated cultures of each of the 6 moulds, a final mixed spore suspension following EN ISO 846 1997, was produced. $5 \mathrm{ml}$ of sterilised water were added to the culture and a sterile needle was used to gently scrape the spores from the surface into the water. The spore suspension was decanted off into a sterile tube and agitated using an orbital shaker and then filtered to remove mycelial fragments. The five spore suspensions were combined together and agitated again.

\section{VOC and water exposure}

The VOCs chosen for this work were formaldehyde (F) (37\% concentration), representative of polar compounds, toluene (T) (99\% concentration), representing aromatic compounds and limonene (L) (99\% concentration), representing non-polar compounds. Samples were also exposed to water (W) as a control.

To expose the modified boards to VOCs and water, $600 \mathrm{ml}$ volume vessels were used. Prior to exposing the samples to the VOCs, the jars and samples were sterilised. This was achieved by spraying the inside of the jars, metal stand and the samples with $70 \%$ ethanol and allowed to dry in sterile conditions. $60 \mathrm{ml}$ of either water or liquid VOC source was poured into the jars with a sterile supporting metal mesh. The samples were placed on top of the mesh, to ensure that the samples were out of contact with the solvents. Each chamber was sealed with an aluminium lid and wrapped with wax film to ensure that no solvent was lost through evaporation. The chambers were then stored for seven days at a constant temperature and humidity of $20^{\circ} \mathrm{C} \pm 2$ at $70 \% \mathrm{RH} \pm 3$.

\section{Inoculation and exposure}

The setup of vessels in which the "flooded" VOC samples were exposed to mould growth, was based on the BSEN 120382002 standard procedure using 600ml vessels with ventilated 
aluminium lids. $80 \mathrm{ml}$ of water agar was poured into each vessel and then autoclaved at 121 ${ }^{\mathrm{O}} \mathrm{C}$ for 50 minutes. Sterile, inert plastic meshes were added to ensure the samples were not in direct contact with the water agar.

Under sterile conditions, two of the board samples were removed from the VOC chambers and into $600 \mathrm{ml}$ vessels on top of the plastic mesh. Each sample was then inoculated with $0.5 \mathrm{ml}$ of the spore suspension. The vessels were then quickly sealed with an aluminium lid. These vessels were then stored in a dark chamber at $20{ }^{\circ} \mathrm{C} \pm 2$ at $70 \% \mathrm{RH} \pm 3$ for two weeks.

\section{Assessment}

For the assessment, the presence or absence of the different mould species was identified and given a score of 1 (present) or 0 (absent) on each of the replicates. A mean value of this was then calculated to show the frequency of growth of all the mould across all replicates i.e. value of 0.5 shows that the mould was present on 3 out of 6 replicates.

The sum of the mean values of frequency of growth was then calculated to show the total frequency of growth of all the moulds collectively. Where possible, the primary, secondary and tertiary colonisers were identified and the dominant mould species identified and recorded.

\section{RESULTS AND DISCUSSION}

\section{Water and VOC Sorption}

Table 1, shows the results of the sorption of water and the three VOCs by the different modified panels. The boards containing 15\% walnut absorbed the most moisture in the water chamber $(1.87 \mathrm{~g} / \mathrm{kg})$ and $5 \%$ walnut, the least $(1.28 \mathrm{~g} / \mathrm{kg})$. Of the formaldehyde VOC, the blank MDF samples, absorbed the most and solid pine wood the least, $1.56 \mathrm{~g} / \mathrm{kg}$ and 0.98 $\mathrm{g} / \mathrm{kg}$, respectively. Panels containing $10 \%$ peanut shall absorbed the most limonene and solid pine the least, $1.17 \mathrm{~g} / \mathrm{kg}$ and $0.35 \mathrm{~g} / \mathrm{kg}$ respectively. Of the toluene, solid pine absorbed the most $(1.55 \mathrm{~g} / \mathrm{kg})$ and $15 \%$ walnut boards absorbed the least $(0.66 \mathrm{~g} / \mathrm{kg})$. Figure 3 graphically shows the results of the water and VOC sorption by the modified panels.

As is obvious, the standard error bars are quite large for the toluene sorption results. This is due to toluene being a volatile compound. Once removed from the chamber, the boards were de-gassing and the free toluene immediately begins to evaporate. It is likely to be the same for limonene sorption, as only some will be bound to the scavenger and MDF (Figure 4).

Table 1: Shows the average sorption of VOCs by modified panels

\begin{tabular}{|l|l|l|l|l|}
\hline Panel & $\begin{array}{l}\text { Water } \\
(\mathrm{g} / \mathbf{k g})\end{array}$ & $\begin{array}{l}\text { Formaldehyde } \\
(\mathbf{g} / \mathbf{k g})\end{array}$ & $\begin{array}{l}\text { Toluene } \\
(\mathbf{g} / \mathbf{k g})\end{array}$ & $\begin{array}{l}\text { Limonene } \\
(\mathrm{g} / \mathrm{kg})\end{array}$ \\
\hline $\mathbf{5 \%}$ Walnut & 1.28 & 1.12 & 0.94 & 0.49 \\
\hline $\mathbf{1 0} \%$ Walnut & 1.53 & 1.17 & 0.87 & 0.74 \\
\hline $\mathbf{1 5} \%$ Walnut & 1.87 & 1.35 & 0.66 & 0.59 \\
\hline $\mathbf{5 \%}$ Peanut & 1.47 & 1.18 & 1.20 & 0.78 \\
\hline $\mathbf{1 0} \%$ Peanut & 1.37 & 1.37 & 1.29 & 1.17 \\
\hline $\mathbf{1 5} \%$ Peanut & 1.52 & 1.52 & 0.67 & 0.48 \\
\hline MDF Blank & 1.56 & 1.56 & 1.00 & 0.91 \\
\hline Pine & 1.43 & 0.98 & 1.55 & 0.35 \\
\hline
\end{tabular}




\section{Mould growth}

2 Table 2 shows the results for the mean frequency of growth of each mould species across the 3 replicates, exposed to water and the four VOCs. Table 3 shows the total frequency of mould 4 growth observed on the modified MDF panels and pine wood. Unfortunately, Chaetomium 5 globosum failed to grow across all the samples. The greatest mould growth was, as expected, 6 observed on the modified boards exposed to water.

\section{Mould growth post water exposure}

9 Aspergillus niger had successfully developed on all types of modified boards and was 10 observed in all replicates. Cladiosporum sphaerospermum and Trichoderma virens were also 11 seen on all types of modified panels, but not of the same frequency as Aspergillus niger. 12 Penicillium rubens was observed on all types of boards but showed the least frequency of 13 growth. However, as a primary coloniser it may have been out-competed by the other 14 secondary and tertiary colonisers over the two weeks.

15 The greatest extent of growth was observed on the 10 and $15 \%$ walnut boards after exposing 16 to water. This is likely to be a result of the higher moisture content of the boards, due to 17 absorbing more moisture when in the chamber (Figure 1).

18 Solid pine showed the lowest frequency of mould growth, after exposure to water. This is 19 likely to be result of the lower moisture sorption, inhibiting the mould growth. 
Table 2: Frequency of species mould growth on samples exposed to water $(W)$, formaldehyde $(F)$, toluene $(T)$ and limonene $(L)$

\begin{tabular}{|c|c|c|c|c|c|c|c|c|c|c|c|c|c|c|c|c|c|c|c|c|}
\hline \multirow[t]{2}{*}{ Panel } & \multicolumn{4}{|c|}{$\begin{array}{l}\text { Chaetomium } \\
\text { globosum }\end{array}$} & \multicolumn{4}{|c|}{ Trichoderma virens } & \multicolumn{4}{|c|}{$\begin{array}{c}\text { Cladiosporum } \\
\text { sphaerospermum }\end{array}$} & \multicolumn{4}{|c|}{ Aspergillus niger } & \multicolumn{4}{|c|}{ Penicillium rubens } \\
\hline & $\mathbf{w}$ & $\mathbf{F}$ & $\mathbf{T}$ & $\mathbf{L}$ & $\mathbf{w}$ & $\mathbf{F}$ & $\mathrm{T}$ & $\mathbf{L}$ & $\mathbf{w}$ & $\mathbf{F}$ & $\mathbf{T}$ & $\mathbf{L}$ & $\mathbf{w}$ & $\mathbf{F}$ & $\mathbf{T}$ & $\mathbf{L}$ & $\mathbf{w}$ & $\mathbf{F}$ & $\mathbf{T}$ & $\mathbf{L}$ \\
\hline $5 \%$ Walnut & 0 & 0 & 0 & 0 & 0.83 & 0 & 0 & 0 & 1 & 0 & 0 & 0 & 1 & 0 & 0 & 0 & 0.83 & 0 & 0 & 0.67 \\
\hline $10 \%$ Walnut & 0 & 0 & 0 & 0 & 1 & 0 & 0 & 0 & 1 & 0 & 0 & 0 & 1 & 0 & 0 & 0 & 1 & 0 & 0.33 & 0.33 \\
\hline $15 \%$ Walnut & 0 & 0 & 0 & 0 & 1 & 0 & 0 & 0 & 1 & 0 & 0 & 0 & 1 & 0 & 0 & 0 & 1 & 0 & 0.17 & 0 \\
\hline $5 \%$ Peanut & 0 & 0 & 0 & 0 & 0.83 & 0 & 0 & 0 & 1 & 0 & 0 & 0 & 1 & 0 & 0 & 0 & 0.5 & 0 & 0 & 0 \\
\hline $10 \%$ Peanut & 0 & 0 & 0 & 0 & 1 & 0 & 0 & 0 & 1 & 0 & 0 & 0 & 1 & 0 & 0.33 & 0 & 0 & 0 & 0.33 & 0 \\
\hline $15 \%$ Peanut & 0 & 0 & 0 & 0 & 1 & 0 & 0 & 0 & 1 & 0 & 0 & 0 & 1 & 0 & 0.33 & 0 & 0.67 & 0 & 0.33 & 0 \\
\hline MDF Blank & 0 & 0 & 0 & 0 & 0.83 & 0 & 0 & 0 & 1 & 0 & 0 & 0 & 1 & 0 & 0 & 0 & 0.5 & 0 & 0.17 & 0 \\
\hline Pine & 0 & 0 & 0 & 0 & 0.00 & 0 & 0 & 0 & 0.50 & 0 & 0.17 & 0 & 1 & 0 & 0 & 0 & 0 & 0 & 0 & 0 \\
\hline
\end{tabular}

Table 3: Total frequency of mould growth on modified MDF, MDF and pine

\begin{tabular}{|l|c|c|c|c|}
\hline \multicolumn{1}{|c|}{ Panel } & Water & Formaldehyde & Toluene & Limonene \\
\hline $\mathbf{5 \%}$ Walnut & 3.67 & 0 & 0 & 0.67 \\
\hline $\mathbf{1 0} \%$ Walnut & 4 & 0 & 0.33 & 0.33 \\
\hline $\mathbf{1 5} \%$ Walnut & 4 & 0 & 0.17 & 0 \\
\hline $\mathbf{5 \%}$ Peanut & 3.33 & 0 & 0 & 0 \\
\hline $\mathbf{1 0} \%$ Peanut & 3.0 & 0 & 0.67 & 0 \\
\hline $\mathbf{1 5} \%$ Peanut & 3.67 & 0 & 0.83 & 0 \\
\hline MDF Blank & 3.33 & 0 & 0.17 & 0 \\
\hline Pine & 1.50 & 0 & 0.17 & 0 \\
\hline
\end{tabular}


Figure 5 shows the differences in the frequency of mould growth of primary, secondary and tertiray colonisers. All primary, secondary and tertiary colonisers were present on all samples tested, except on pine samples. On pine samples, only primary and secondary colonisers were observed. This could be a result of the pine having a lower moisture content than MDF samples. There is little difference between the samples, however there is a difference between the dominating species (Table 4).

\section{Mould growth post formaldehyde exposure}

Across all the modified boards and replicates, no mould growth of any mould species was observed (Table 2). Formaldehyde is toxic (Rong et al., 2002; Rosenkranz, 1972) and therefore the lack of mould growth is not surprising. Of the VOCs tested, formaldehyde was absorbed to the greatest extent by the modified boards, see Table 1 and Figure 2. The formaldehyde used was in an aqueous solution at $37 \%$, therefore part of the observed weight gain after absorption is likely to be water as well as formaldehyde. However, there was a total absence of mould growth, compared to samples exposed to water alone. This shows that a sufficient amount of formaldehyde was absorbed to prevent any mould growth. This also shows that the presence of formaldehyde in the resins is not responsible for the lack of mould growth, as all panel samples underwent the same de-gassing period to remove any free formaldehyde.

As mould growth was not observed on solid pine, this indicates that wood can absorb enough formaldehyde to prevent mould growth too. However, this experiment was not continued after two weeks. Therefore it is possible that the formaldehyde was not trapped within the pine wood chemically and would eventually de-gas and mould would colonise and grow on the wood.

\section{Mould growth post toluene sorption}

Little growth was observed on the toluene exposed samples, see Table 2. Only primary colonisers were observed towards the end of the two weeks of the experiment on $10 \%$ and $15 \%$ Walnut and peanut MDF boards. Figure 6 and 7 shows that there is no correlation between fungal growth and the amount of toluene absorption on all peanut and walnut modified panels respectively. It is possible that due to the off-gassing from the sample of free toluene, toluene gas could have accumulated inside the vessels to toxic level, preventing the growth of mould species. The vessels were all tightly sealed with a plugged hole of nonabsorbent cotton wool to allow oxygen ventilation. Therefore, over the two weeks experimental time, the oxygen levels will have increased and the toluene levels decreased inside the vessels. Eventually, this allowed for primary colonisers, Aspergillus niger and Penicillium rubens to grow and establish on the exposed MDF boards. If allowed more time to grow, it is possible that more growth and further colonisation may occur. This suggests that, although a lot of toluene was not chemically bound within the panel, it can reduce the time for colonisation, growth and succession.

\section{Mould growth post limonene sorption}

Table 2 shows the subsequent results of the mould growth on the boards. Minimal growth was observed on the 5\% and 10\% walnut boards and only of the primary coloniser Penicillium rubens. No growth was observed on all other boards. This suggests that peanut shell maybe a better scavenger than walnut shell for non-polar compounds. This is important 
when considering what scavengers to use for target VOCs. Figure 6 and 7 shows that there is no correlation between fungal growth and the amount of limonene absorption on peanut and walnut modified panels respectively. However, when compared to the growth on samples exposed to water, there is a marked reduction in growth, so the presence of limonene is preventing mould growth.

\section{Dominating species}

Table 4 shows the dominant species found on the different types of modified boards exposed to water, toluene and limonene. Formaldehyde is not included in Table 4, as there was no growth observed for any of the test moulds.

Table 4: Dominant species found modified boards

\begin{tabular}{|c|c|c|c|}
\hline Panel & Water & Toluene & Limonene \\
\hline $5 \%$ Walnut & A. niger & - & P. rubens \\
\hline $10 \%$ Walnut & C.sphaerospermum & P. rubens & P.rubens \\
\hline $15 \%$ Walnut & A. niger & P. rubens & - \\
\hline $5 \%$ Peanut & $\begin{array}{l}\text { C.sphaerospermum } \\
\text { A. niger }\end{array}$ & - & - \\
\hline $10 \%$ Peanut & T. virens, A. niger & P. rubens & - \\
\hline $15 \%$ Peanut & A. niger, & $\begin{array}{l}\text { P. rubens } \\
\text { A. niger }\end{array}$ & - \\
\hline MDF Blank & $\begin{array}{l}\text { A. niger, } \\
\text { C. sphaerospermum }\end{array}$ & - & - \\
\hline Pine & A. niger & - & - \\
\hline
\end{tabular}

Key: - no mould growth observed

On samples exposed to water, a different succession of growth was observed. On boards containing 5\% walnut, although Table 2 shows primary, secondary and tertiary species present, the dominant mould species was a primary coloniser Aspergillus niger. Aspergillus niger was also a dominant species on the boards containing $15 \%$ walnut. This suggests a slower succession of growth of the mould species grown on boards containing a walnut scavenger.

There was a lower frequency of growth on the boards containing peanut shells, when compared against those boards containing walnut shell. There was also a difference in the specific species growing and their prevalence on the peanut samples. Although primary colonisers are still present, the secondary and tertiary colonisers are more dominant. This suggests a difference in the growth rate of the moulds on boards containing peanut shell, compared to boards containing walnut shell.

The mould growth observed on limonene and toluene exposed samples is by the primary coloniser Penicillium rubens. Primary coloniser Aspergillus niger, was observed only on boards containing $15 \%$ peanut exposed to toluene. This shows that the presence of these two VOCs significantly reducing colonisation, when compared to samples exposed to water. 


\section{CONCLUSION}

The aim of this paper was to evaluate the addition of organic scavengers on absorption of VOCs and the effect this has on mould growth. The study conducted suggests that the addition of the walnut shell increases the boards' susceptibility to mould colonisation and growth. This is possibly due to an increased moisture uptake by the walnut. The presence of peanut scavenger also seems to increase vulnerability but to a lesser extent. It can also be concluded that the boards modified by the addition of walnut shell or peanut shell do absorb formaldehyde, toluene and limonene. The absorption of formaldehyde from the atmosphere by the scavengers prevents colonisation and initial growth. This sorption of VOCs does effect mould growth on boards, reducing frequency as well as causing a variation in the presence of different mould species.

\section{ACKNOWLEDGMENT}

The results presented in this paper are part of the ECO-SEE project which has received funding from the European Union's Seventh Framework Programme for research technological development and demonstration under grant agreement no 609234.

\section{REFERENCES}

BS 1982-3 1990, Fungal resistance of panel products made of or containing materials of organic origin - Part 3: Methods of determination of resistance to mould or mildew. Second edition 1990

BSEN 12038 : 2002, Durability of wood and wood-based panels - Wood-based panels Method of test for determining the resistance against wood-destroying basidiomycetes

EN ISO 846 : 1997, Plastics - Evaluation of the action of microorganisms, Second edition 1997

Curling, S.F., Murphy, R.J., 1997. The effect of artificial ageing on the durability of woodbased board materials against basidiomycete decay fungi. Wood Sci. Technol. 33, 245-257. doi:10.1007/s002260050113

Deng, S., Hu, B., Chen, T., Wang, B., Huang, J., Wang, Y., Yu, G., 2015. Activated carbons prepared from peanut shell and sunflower seed shell for high CO2. Adsorption 21, 125-133. doi:10.1007/s10450-015-9655-y

Dennis, C., Gaunt, H., 1974. Effect of Formaldehyde on Fungi from Broiler Houses. J. Appl. Bacteriol. 37, 595-601. doi:10.1111/j.1365-2672.1974.tb00484.x

Fog Nielsen, K., 2003. Mycotoxin production by indoor molds. Fungal Genet. Biol. 39, 103117. doi:10.1016/S1087-1845(03)00026-4

Jarvis, B.B., Miller, J.D., 2004. Mycotoxins as harmful indoor air contaminants. Appl. Microbiol. Biotechnol. 66, 367-372. doi:10.1007/s00253-004-1753-9

Johns, M.M., Marshall, W.E., Toles, C.A., 1998. Agricultural by-products as granular activated carbons for adsorbing dissolved metals and organics. J. Chem. Technol. Biotechnol. 71, 131-140. doi:10.1002/(SICI)1097-4660(199802)71:2<131::AIDJCTB821>3.0.CO;2-K

Kim, D.I., Park, J.H., Kim, S.D., Lee, J.-Y., Yim, J.-H., Jeon, J.-K., Park, S.H., Park, Y.-K., 2011. Comparison of removal ability of indoor formaldehyde over different materials functionalized with various amine groups. J. Ind. Eng. Chem. 17, 1-5. doi:10.1016/j.jiec.2010.12.010

Kim, J.-W., Sohn, M.-H., Kim, D.-S., Sohn, S.-M., Kwon, Y.-S., 2001. Production of granular activated carbon from waste walnut shell and its adsorption characteristics for $\mathrm{Cu} 2+$ ion. J. Hazard. Mater. 85, 301-315. doi:10.1016/S0304-3894(01)00239-4 
Kim, S., 2009. The reduction of indoor air pollutant from wood-based composite by adding pozzolan for building materials. Constr. Build. Mater. 23, 2319-2323. doi:10.1016/j.conbuildmat.2008.11.008

Pasanen, A.-L., Juutinen, T., Jantunen, M.J., Kalliokoski, P., 1992. Occurrence and moisture requirements of microbial growth in building materials. Int. Biodeterior. Biodegrad. 30, 273-283. doi:10.1016/0964-8305(92)90033-K

Pirayesh, H., Khanjanzadeh, H., Salari, A., 2013. Effect of using walnut/almond shells on the physical, mechanical properties and formaldehyde emission of particleboard. Compos. Part B Eng. 45, 858-863. doi:10.1016/j.compositesb.2012.05.008

Rong, H., Ryu, Z., Zheng, J., Zhang, Y., 2002. Effect of air oxidation of Rayon-based activated carbon fibers on the adsorption behavior for formaldehyde. Carbon 40, 2291-2300. doi:10.1016/S0008-6223(02)00109-4

Rosenkranz, H.S., 1972. Formaldehyde as a possible carcinogen. Bull. Environ. Contam. Toxicol. 8, 242-244. doi:10.1007/BF01839520

Schmidt, 2006. Wood and Tree Fungi: Biology, Damage, Protection and Use [WWW Document]. URL (accessed 7.11.16).

Tavakoli Foroushani, F., Tavanai, H., Hosseini, F.A., 2016. An investigation on the effect of $\mathrm{KMnO} 4$ on the pore characteristics of pistachio nut shell based activated carbon. Microporous Mesoporous Mater. 230, 39-48. doi:10.1016/j.micromeso.2016.04.030

Viitanen, H., 1994. Factors affecting the development of biodeterioration in wooden constructions. Mater. Struct. 27, 483-493. doi:10.1007/BF02473453

Witek-Krowiak, A., Szafran, R.G., Modelski, S., 2011. Biosorption of heavy metals from aqueous solutions onto peanut shell as a low-cost biosorbent. Desalination 265, 126134. doi:10.1016/j.desal.2010.07.042

XU, T., LIU, X., 2008. Peanut Shell Activated Carbon: Characterization, Surface Modification and Adsorption of $\mathrm{Pb} 2+$ from Aqueous Solution. Chin. J. Chem. Eng. 16, 401-406. doi:10.1016/S1004-9541(08)60096-8

Zhang, Y., Xu, Y., 2003. Characteristics and correlations of VOC emissions from building materials. Int. J. Heat Mass Transf. 46, 4877-4883. doi:10.1016/S00179310(03)00352-1

World Health Organization, 1989. Indoor Air Quality: Organic Pollutants. EURO Reports and Studies No. 111, World Health Organization, Copenhagen 


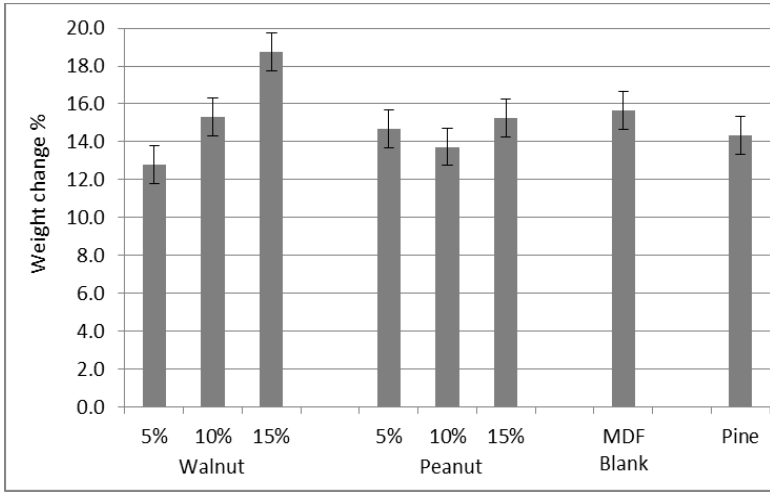

Figure 1: Water sorption

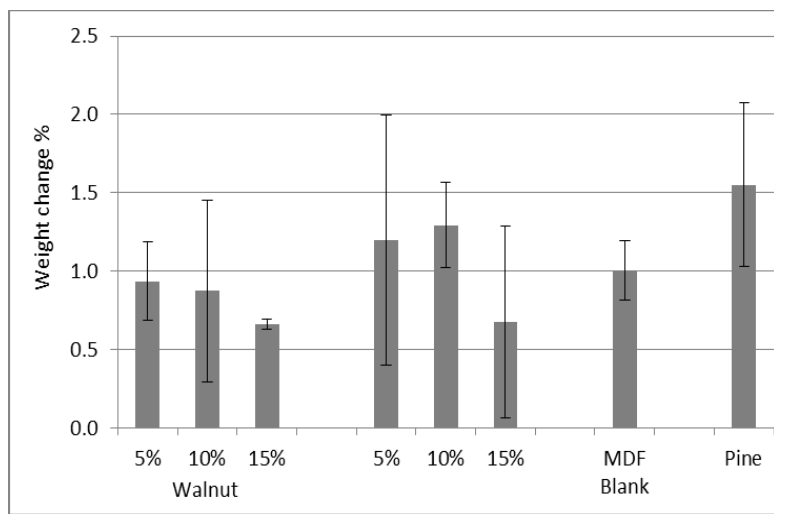

Figure 3: Toluene sorption

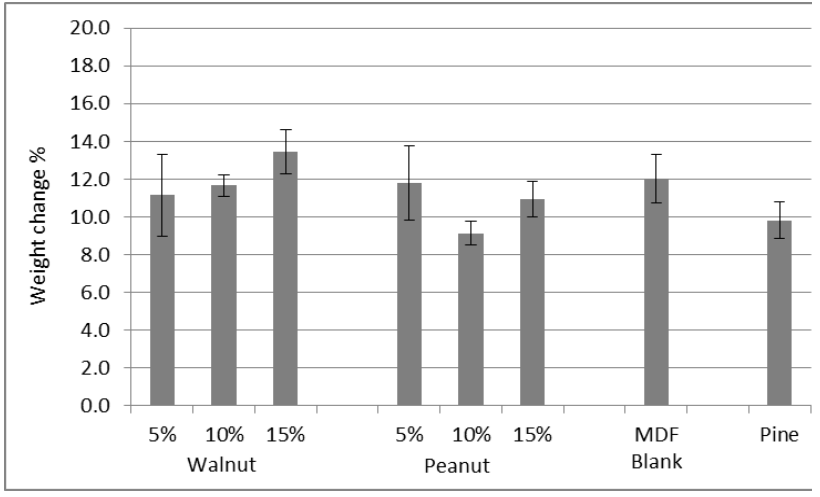

Figure 2: Formaldehyde sorption

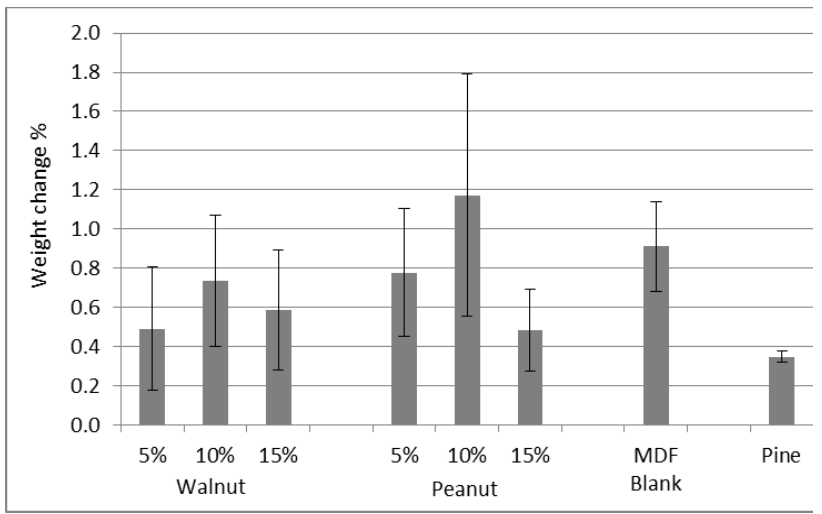

Figure 4: Limonene sorption

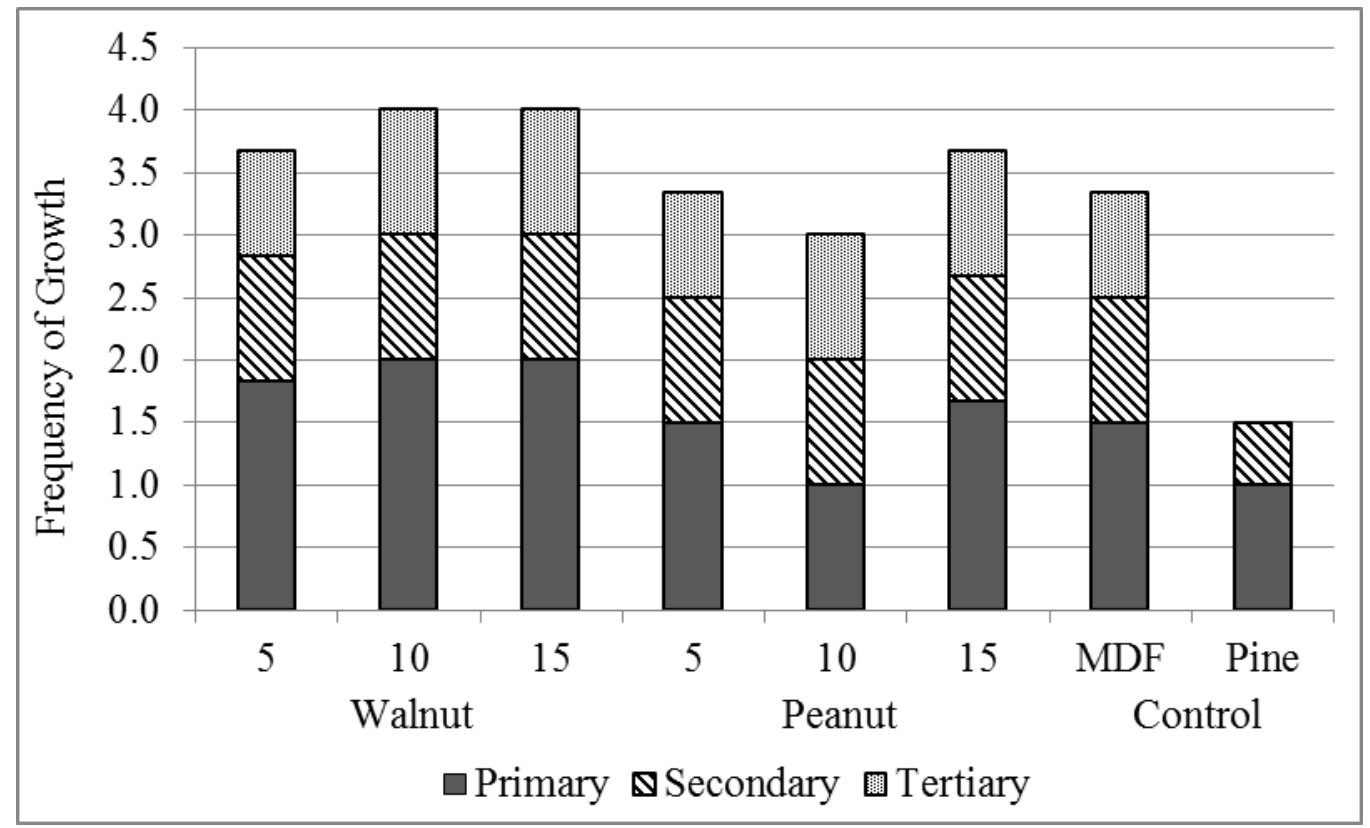

Figure 5: Total frequency of colonising mould specie's growth and the different colonising species on modifed boards after water exposure 


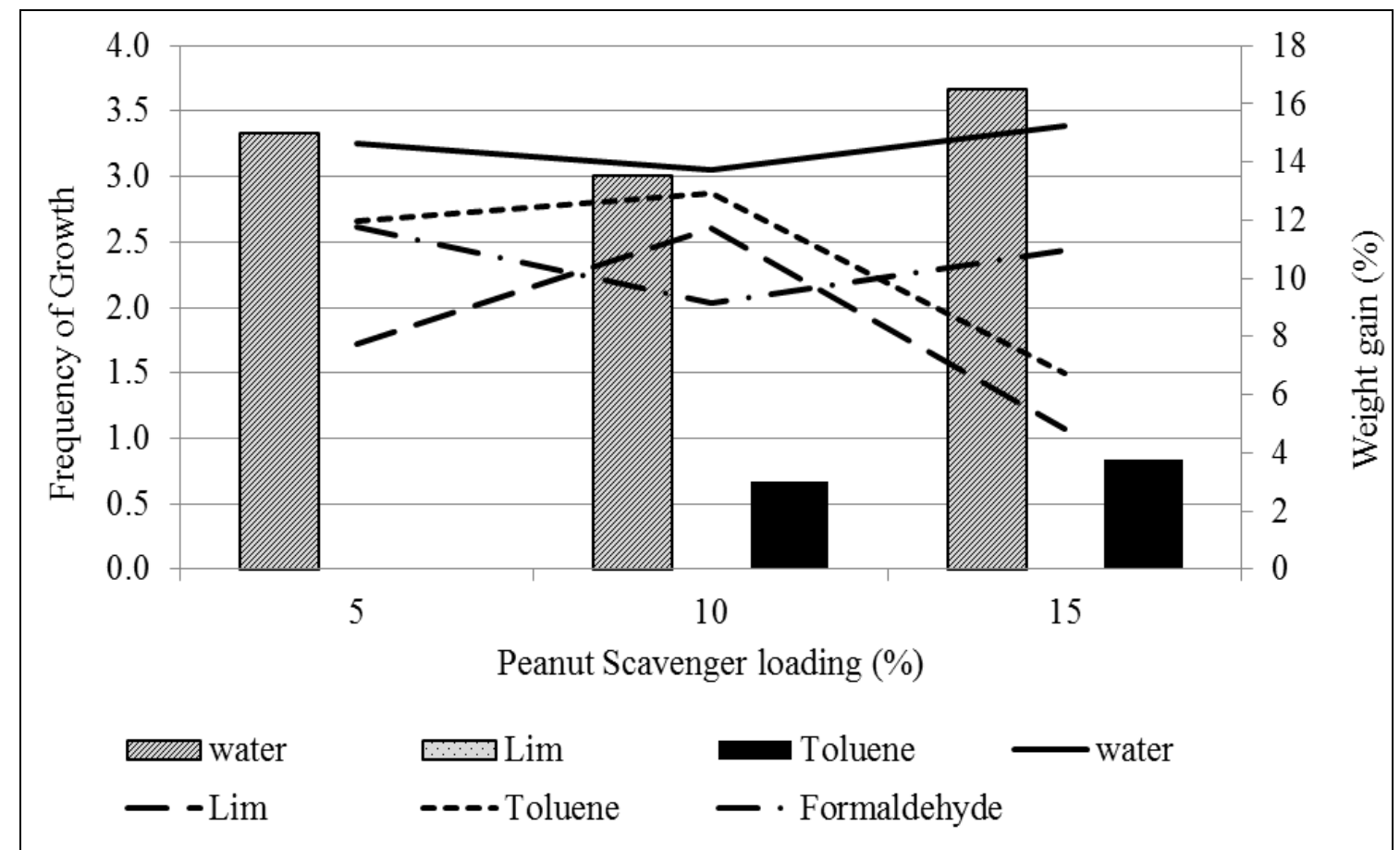

Figure 6: Frequency of mould growth (bars) and sorption weight gain (\%) (lines) of MDF panels modified with peanut shell

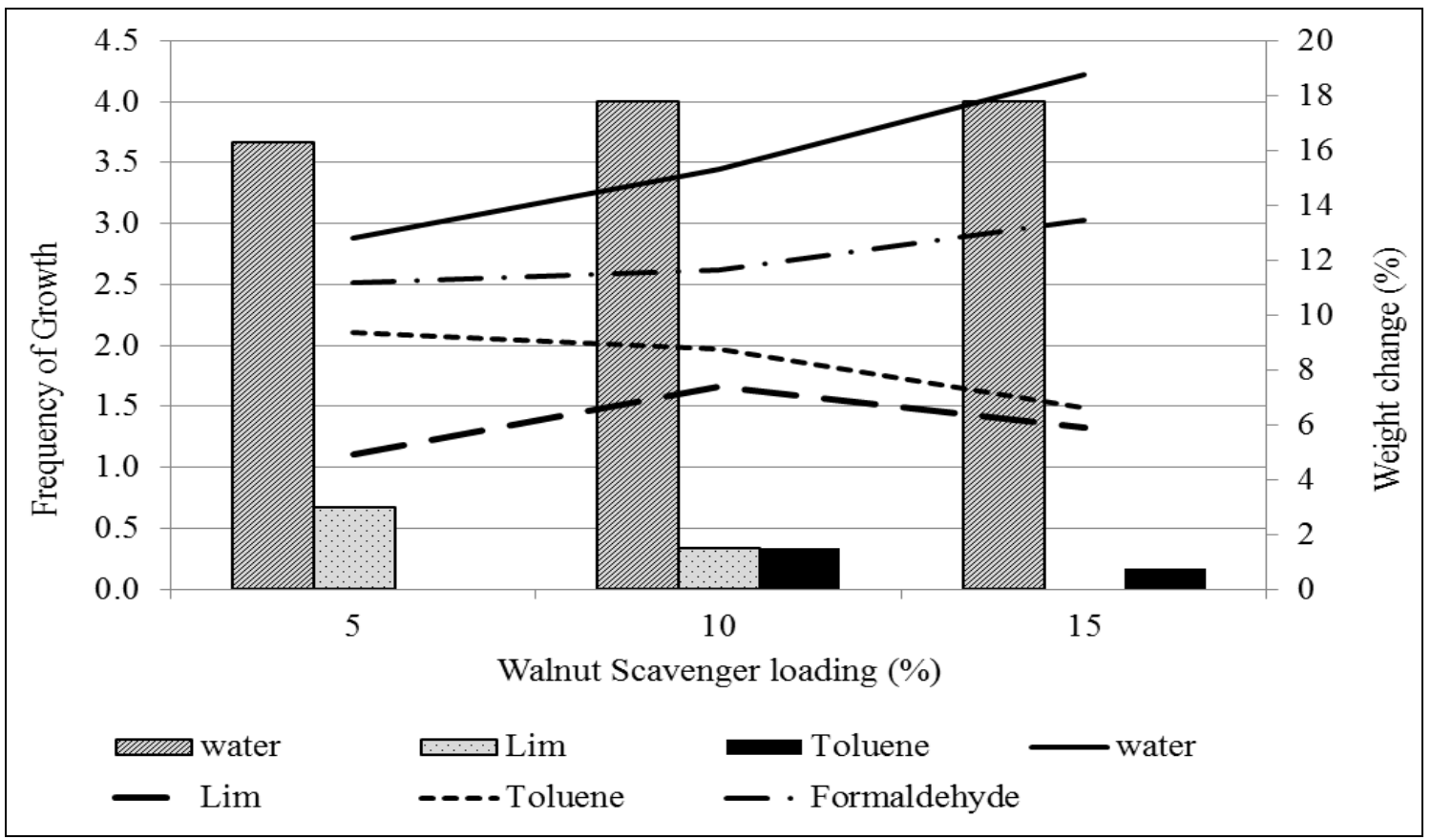

Figure 7: Frequency of mould growth (bars) and sorption weight gain (\%) (lines) of MDF panels modified with walnut shell 